\title{
Neurotrophic Factors Increase Neuregulin Expression in Embryonic Ventral Spinal Cord Neurons
}

\author{
Jeffrey A. Loeb and Gerald D. Fischbach \\ Department of Neurobiology, Harvard Medical School, Boston, Massachusetts 02115
}

Neuregulins (NRGs) are expressed in spinal cord motor neurons and accumulate at the neuromuscular junction where they may increase the synthesis of postsynaptic acetylcholine receptors and voltage-gated sodium channels. We demonstrate here that NRG expression is selectively increased in rat ventral spinal cord neurons at approximately the time that nervemuscle synapses first form. A rapid increase in NRG mRNA and protein expression was induced in vitro in cultured rat spinal motor neurons by brain-derived neurotrophic factor, neurotrophin-3, neurotrophin-4, or glial-cell-line-derived neurotrophic factor. Agrin expression was not affected by these factors over the same time course. Brain-derived neurotrophic factor, but not neurotrophin-3, selectively regulated immunoglobulin domain-containing splice variants of NRG, which are likely to be important for binding to the synaptic basal lamina. Regulation of NRG expression in motor neurons by musclederived neurotrophic factors may represent one portion of a reciprocal, regulatory loop that promotes neuromuscular synapse development.

Key words: ARIA; neuregulin; neurotrophin; motor neuron; agrin; GDNF; BDNF; NT-3; NT-4
Acetylcholine receptor-inducing activity (ARIA) is a polypeptide that was purified based on its ability to increase the expression of acetylcholine receptors (AChRs) in cultured skeletal muscle (Falls et al., 1993). It is expressed in embryonic and adult motor neurons (Corfas et al., 1995) and is concentrated in the basal lamina of the neuromuscular synapse (Goodearl et al., 1995; Jo et al., 1995). ARIA is one of a growing family of soluble factors that activate receptor protein-tyrosine kinases related to the epidermal growth factor (EGF) receptor, and are all derived from a common gene through alternative splicing (Peles and Yarden, 1993). Other members of this family include Neu differentiation factor (NDF), heregulin, and glial growth factor each named for diverse biological effects both in and out of the nervous system (for review, see Lemke, 1996). The term neuregulin (NRG) has been suggested to describe all of the splice variants within this family (Marchionni et al., 1993). NRGs at the neuromuscular junction almost certainly activate AChR genes by inducing tyrosine phosphorylation on their receptors erbB2, erbB3, and erbB4 (Carraway and Cantley, 1994) that have been shown to be present in the postsynaptic muscle membrane (Altiok et al., 1995; Moscoso et al., 1995; Zhu et al., 1995).

Several lines of evidence indicate that target-derived factors influence both the survival and the differentiation of motor neurons. Brain-derived neurotrophic factor (BDNF), neurotrophin-3 (NT-3), and glial-cell-line-derived neurotrophic factor (GDNF)

Received Sept. 24, 1996; revised Dec. 2, 1996; accepted Dec. 5, 1996.

This work was supported by Clinical Investigator Development Award K08 NS01659-02 from the National Institute of Neurological Disorders and Stroke (J.A.L.) and grants from National Institutes of Health (NS18458) and the Charles A Dana Foundation. We thank Janet Robbins for assistance with preparation of neuronal cultures, Gabriel Corfas for help with in situ hybridization studies, and Michael Greenberg for thoughtful comments. We also thank AMGEN (Thousand Oaks, CA) for their generous supply of BDNF, NT-3, NDF, and cDNA probes for BDNF and NT-3; Kathy Buckley for probes for synaptotagmin-I and synaptophysin; and Regeneron (Tarrytown, NY) for recombinant CNTF.

Correspondence should be addressed to Dr. Gerald D. Fischbach, Department of Neurobiology, Harvard Medical School, 220 Longwood Avenue, Boston, MA 02115. Copyright (C) 1997 Society for Neuroscience $0270-6474 / 97 / 171416-09 \$ 05.00 / 0$ are expressed in embryonic rat muscle at the time of nerve-muscle contact (Schecterson and Bothwell, 1992; Henderson et al., 1993; Trupp et al., 1995). They have been shown to rescue motor neurons from cell death either when cultured at low cell density under serum-free conditions (Henderson et al., 1993, 1994) or after axotomy in vivo (Koliatsos et al., 1993). Embryonic rat motor neurons express $t r k B$, trkC, and GDNFR- $\alpha$, the receptors for BDNF, NT-3, and GDNF, respectively (Henderson et al., 1993; Jing et al., 1996). BDNF and NT-3 have been shown to be retrogradely transported to the motor neuron cell body (Koliatsos et al., 1993). Postnatally, during the time of synapse elimination, BDNF and NT-3 levels fall and neurotrophin-4 (NT-4) becomes the prominent neurotrophin expressed by muscle (Funakoshi et al., 1995). Individual deletions of BDNF, NT-3, GDNF, and/or their receptors by homologous recombination has lead to only modest reductions in motor neurons (for review, see Snider, 1994; Moore et al., 1996; Sanchez et al., 1996). However, there is now increasing evidence that these factors play important roles in activity-dependent synaptic plasticity both at the neuromuscular junction and in the CNS (Lewin and Barde, 1996).

We have begun to characterize the interactions between targetderived neurotrophic factors and NRGs at the neuromuscular junction. Here, we demonstrate an increase of NRG expression in motor neurons in vivo at the time of early axonal contact with muscle. We provide in vitro evidence that BDNF, NT-3, NT-4, and GDNF may contribute to this striking induction. Moreover, alternatively spliced forms of NRG may be differentially regulated by BDNF and NT-3. We suggest that regulation of NRG expression by target-derived neurotrophic factors is part of a reciprocal regulatory loop that may serve to reinforce and maintain synaptic connections.

\section{MATERIALS AND METHODS}

Ventral spinal cord and myotube cultures. Ventral spinal cords were dissected from timed pregnant Sprague Dawley rat embryos (Charles River Labs, Wilmington, MA). Cultures of ventral horn neurons were prepared from the anterior two-thirds spinal cords of embryonic day 15 
(E15) rat embryos, similar to that described by Henderson (1993), but without any subsequent purification of motor neurons. Cells were plated at 200,000 cells $/ \mathrm{cm}^{2}$ on $60 \mathrm{~mm}$ plastic tissue culture dishes for Northern blot analysis or at $300,000 \mathrm{cell} / \mathrm{cm}^{2}$ on Superfrost/Plus (Fisher Scientific, Pittsburgh, PA) glass slides for in situ hybridization. Flexiperm chambers were applied to the slides according to the manufacturer's instructions (Haraeus Biotech, Hanau, Germany). The dishes or slides were coated overnight at $37^{\circ} \mathrm{C}$ with $5 \mu \mathrm{g} / \mathrm{ml}$ poly-lysine (Sigma, St. Louis, MO) and 2 $\mu \mathrm{g} / \mathrm{ml}$ laminin (Life Technologies, Grand Island, NY) and washed twice with sterile water. The culture medium consisted of L15 Glutamax (Life Technologies) supplemented with 1:100 N2 additives (Life Technologies) $6 \mu \mathrm{g} / \mathrm{ml}$ chick E11 pectoral muscle extract, $6 \mathrm{~mm} \mathrm{NaHCO}_{3}, 1: 100$ stable vitamin mix (basal medium eagle vitamin solution (Life Technologies) containing $0.1 \mathrm{mg} / \mathrm{ml}$ lipoic acid, $0.4 \mathrm{mg} / \mathrm{ml}$ vitamin B12, $0.08 \mathrm{mg} / \mathrm{ml}$ coenzyme A, $3 \mathrm{mg} / \mathrm{ml} \mathrm{L}$-proline, and $3 \mathrm{mg} / \mathrm{ml} \mathrm{L}$-cysteine), $54 \mu \mathrm{g} / \mathrm{ml}$ imidazole, and penicillin/streptomycin (Life Technologies). Chick pectoral muscle extract was prepared by Polytron homogenation (Brinkmann, Germany) of E11 chick pectoral muscle in PBS containing 2 mM EDTA, $0.5 \mu \mathrm{g} / \mathrm{ml}$ pepstatin, $1 \mu \mathrm{g} / \mathrm{ml}$ leupeptin, $17 \mu \mathrm{g} / \mathrm{ml}$ PMSF for $75 \mathrm{sec}$ at $15,000 \mathrm{rpm}$, followed by removing insoluble material by centrifugation at 40,000 $\mathrm{g}$ for $1 \mathrm{hr}$

Rat myotube cultures were prepared from enzymatically dissociated E20 rat muscles, as described by Daniels (1990), on $60 \mathrm{~mm}$ plastic tissue culture dishes coated with collagen. Treatment with NRG was performed $5 \mathrm{~d}$ after changing to differentiation medium yielding large, fused myotubes.

Northern blot analysis of tissues and cultures. Total RNA was isolated from embryonic spinal cords by homogenization in Ultraspect (Biotecx Labs, Houston, TX) or from cultured neurons by first rinsing with PBS, adding Ultraspect directly to the dish, and then scraping cells into the solution. Total RNA was prepared according to the manufacturers. Northern blot analysis was performed as described previously (Corfas et al., 1995) using $5 \mu \mathrm{g}$ of RNA per lane. A $690 \mathrm{bp}$ cDNA probe consisting of most of the extracellular domain of the $\beta 1$ isoform of rat NRG from Pro-37 to Val-262, including both the EGF-like and the immunoglobulin (IG)-like domains (Corfas et al., 1995), was used for random priming labeling using Prime-it II (Stratagene, La Jolla, CA). A 575 bp rat agrin probe was prepared from E17 rat ventral spinal cord RNA by RT-PCR amplification using the following two primers: TGCTGACTCAGGAGCATGTGTTG and TCCATCTGTGTCCAGTTGCGTG.

For the cultured ventral spinal neurons, 5 pg of an $\sim 800$ bp RNA loading standard antisense to the radio-labeled probe was added to samples immediately after cell lysis. Quantitation of transcripts from Northern blots was performed using a Molecular Dynamics (Sunnyvale, CA) phosphoimager. Relative mRNA levels were calculated by first normalizing either individual transcripts or the sum of all of the NRG transcripts to the internal NRG loading standard in the same lane. These values were then divided by similarly obtained values from control cultures and expressed as a ratio to control.

BDNF, NT-3, and recombinant NRG (human NDF $\beta 1_{14-246}$ ) were provided by AMGEN, Thousand Oaks, CA; 2.5S NGF and leukemiainhibitory factor (LIF) were obtained from Life Technologies; NT-4 and GDNF were obtained from Intergen, Purchase, NY; and CNTF was provided by Regeneron, Tarrytown, NJ.

In situ hybridization and immunohistochemistry. For in situ hybridization analysis, a $385 \mathrm{bp}$ antisense or sense probe corresponding to the rat $\beta 1$-EGF-like domain of NRG was used, as described by Corfas et al. (1995) for both tissue sections and cultured neurons, except the protease step was omitted. Transverse sections $(20 \mu \mathrm{M})$ through the brachial region of the spinal cord were prepared from whole embryos fixed in $4 \%$ paraformaldehyde. Cultured neurons were fixed for $15 \mathrm{~min}$ in $4 \%$ paraformaldehyde, dehydrated, and processed as above.

When combined with islet- $1 / 2$ immunofluorescence, tissue sections or cultured neurons were first stained with a 1:10 dilution of a mouse monoclonal antibody hybridoma supernatant 40.2D6 that recognizes both islet- 1 and islet- 2 in sterile PBS $/ 0.1 \%$ Triton X-100 overnight at $4{ }^{\circ} \mathrm{C}$. 40.2D6 was obtained from the Developmental Studies Hybridoma Bank, University of Iowa under contract N01-HD-6-2915 from the National Institute of Child Health and Human Development. Slides were washed twice with PBS for $5 \mathrm{~min}$, then treated for $1 \mathrm{hr}$ with goat anti-mouse antibody conjugated to Cy-3 at 1:500 (Jackson ImmunoResearch, West Grove, PA) in the same solution used for the primary. After washing twice with sterile PBS, the sections were then fixed again with $4 \%$ paraformaldehyde for $5 \mathrm{~min}$, washed twice with PBS, and processed as above.
Photographs of in situs were taken using immunofluorescence using a Cy-3 filter, dark-field, bright-field, or DIC optic on a Nikon Microphot microscope. Some bright-field (see Fig. $6 E, F$ ) and fluorescent images (see Fig. $7 B, D$ ) were combined digitally with DIC images after scanning the photographs.

In situ grains for NRG message were counted over motor neurons identified by double labeling with islet- $1 / 2$ immunofluorescence for control (205 cells) and BDNF-treated (207 cells) neurons. A histogram demonstrated two overlapping peaks centered at 7 and 17 grains/cell that could be fitted to normal distribution curves. A cut-off of 3 SDs above the first peak (16 grains/cell), corresponding to nonspecific background, was used to tabulate islet-1/2-positive neurons clearly containing NRG message.

Measurement of NRGs released from cultured neurons. Ventral spinal cord cultures ( $3 \mathrm{~d}$ old) were treated with either $100 \mathrm{ng} / \mathrm{ml}$ BDNF, NT-3, or BSA carrier in L15 Glutamax medium alone for $3 \mathrm{~d}$. The conditioned medium was concentrated 15 -fold using a Centricon-10 device (Amicon, Beverly, MA). Some of this concentrated medium was mixed with heparin (Sigma) at a final concentration of $500 \mu \mathrm{g} / \mathrm{ml}$ before assaying activity by tyrosine phosphorylation of the NRG receptor p185 in L6 muscle cells by Western blot analysis (Loeb and Fischbach, 1995). L6 cells were also treated with or without 10 pM NRG (NDF $\beta 1_{14-246}$ ) as a control. Quantitation was obtained by densitometry. No effect on p185 was observed by medium, BDNF, or NT-3 that had not been conditioned by neurons.

\section{RESULTS}

\section{NRG expression in ventral spinal cord increases at the time of innervation}

The Northern blot in Figure 1 shows the pattern of NRG mRNA expression in the cervical/brachial rat ventral spinal cord between E12 and postnatal day 1 (P1). NRG mRNA increases between E12 and E14 is reduced at E15, then increases again after E16. The initial increase corresponds to the time when motor neuron axons emerge from the spinal cord and contact adjacent myotomes (Altman and Bayer, 1984), and the later, larger peak at E17-E19 corresponds to the time when the motor growth cones reach the developing limb bud and contact maturing myotubes (Altman and Bayer, 1984). By E17, AChRs and acetylcholinesterase have begun to accumulate at newly formed endplates (Bevan and Steinbach, 1977). The dip at E15 corresponds to the period of maximal motor neuron cell death (Harris and McCaig, 1984). We observed a similar pattern of NRG expression in the lumbar ventral spinal cord. This pattern of expression is consistent with the possibility NRG mRNA is induced by target-derived factors.

Agrin is instrumental for the clustering of postsynaptic AChRs at synaptic contact sites and is also selectively expressed in spinal motor neurons (Nastuk and Fallon, 1993; Gautam et al., 1996). Although agrin expression follows a similar developmental pattern as NRG (Fig. 1 $A$ ), at E17-E19, the induction of NRG exceeds that of agrin by at least a factor of two (Fig. $1 B$ ). Thus, the expression of these two crucial proteins may not be regulated in exactly the same way.

\section{Neurotrophic factors increase NRG expression in cultured ventral spinal cord neurons}

To identify candidate molecules that may mediate this induction of NRG expression in vivo, we looked at the effects of neurotrophic factors on NRG mRNA in cultured neurons dissociated from the ventral halves of E15 rat spinal cords. Cultures were grown at high cell density to maximize neuronal survival and without serum to suppress the proliferation of glia. Under these conditions, very few glia were present and cultures remained viable without appreciable cell loss for $>1$ week. Approximately $5 \%$ of the neurons could be positively identified as motor neurons by their expression of islet-1/2 and/or the p75 NGF receptor (Henderson et al., 1993). 

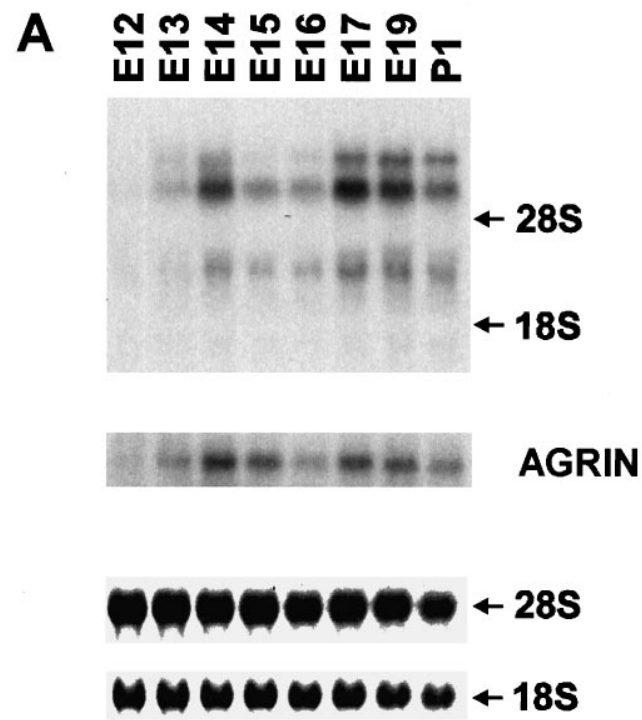

B

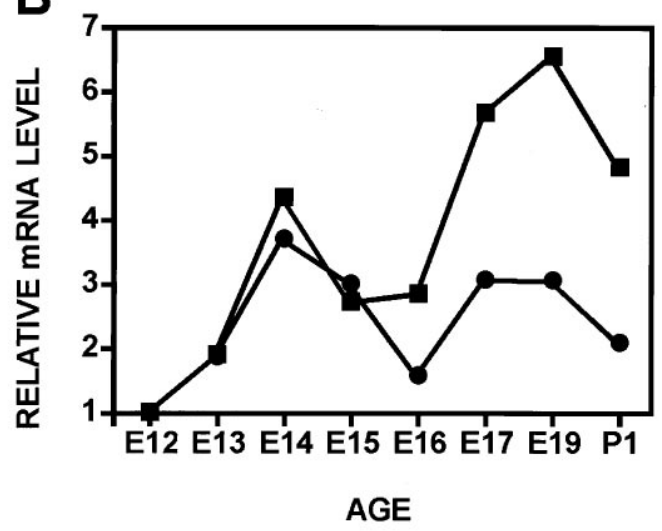

Figure 1. Developmental expression of NRG in the rat spinal cord. Northern blot analysis $(A)$ and phosphoimager quantitation $(B)$ of NRG $(\square)$ and agrin $(\bullet)$ mRNA were obtained from ventral two-thirds spinal cords $(E 14-P 1)$ or whole spinal cords (E12 and E13). Uniformity of loading was verified by $18 \mathrm{~S}$ and $28 \mathrm{~S}$ RNA. Top $(12 \mathrm{~kb})$, middle $(9 \mathrm{~kb})$, and bottom $(3.5 \mathrm{~kb})$ transcripts were seen. The filter was stripped and reprobed with a rat agrin cDNA probe demonstrating the $8 \mathrm{~kb}$ transcript.

Figure 2 shows a Northern blot measuring the time course of NRG mRNA expression after the combined administration of BDNF and NT-3 to 3-d-old cultures. We observed a rapid induction of NRG mRNA (approximately two-to threefold) that peaked at $\sim 4 \mathrm{hr}$ and remained elevated for $>24 \mathrm{hr}$ in the continued presence of the two neurotrophins. In control, untreated cultures, NRG expression remained constant over this $24 \mathrm{hr}$ period. This effect was selective in that proteins common to many neurons, such as synaptophysin and synaptotagmin-I, were unchanged (Fig. 2A).

Rapid induction of NRG expression was seen with BDNF, NT-3, NT-4, and GDNF, but not with NGF, LIF, CNTF, or with NRG itself (Fig. 3A,B). We consistently saw greater effects with the $t r k B$ receptor-specific ligands BDNF and NT-4 than NT-3 or GDNF. Combinations of BDNF with either NT-3 or GDNF, but not CNTF, were partially additive at saturating concentrations of each (data not shown). Interestingly, the expression of agrin, crucial for AChR aggregation, was not affected by any of these neurotrophic factors (Fig. $3 A$ ).
A $\begin{array}{lllllllll}0 & 2 & 4 & 6 & 8 & 12 & 24 & 24-\text { Hours }\end{array}$

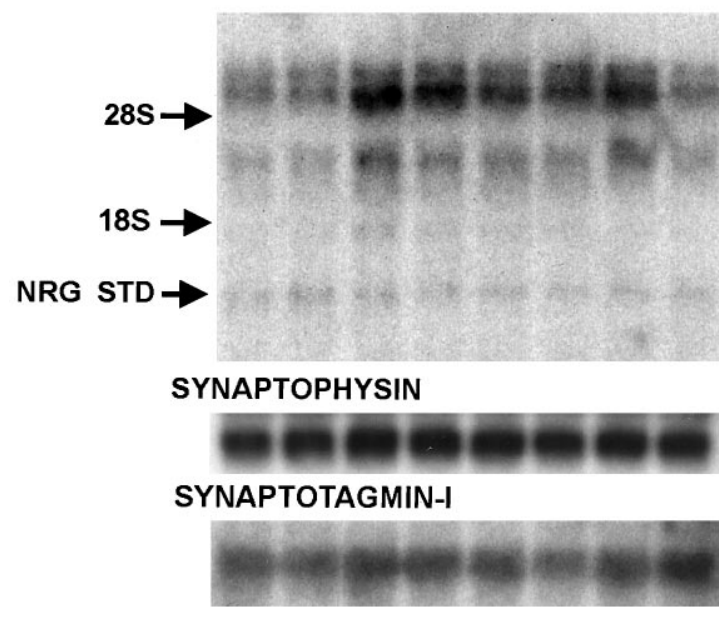

B

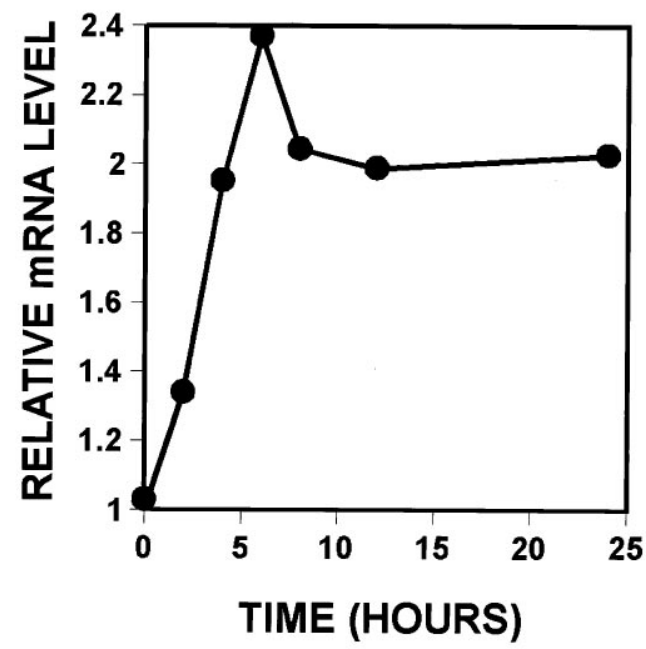

Figure 2. BDNF and NT-3 rapidly and selectively increase NRG expression. $A$, Within $4 \mathrm{hr}$ of treatment with BDNF and NT-3 (at $100 \mathrm{ng} / \mathrm{ml}$ each), NRG expression increased by two- to threefold by Northern blot analysis of 3-d-old cultures. The effect peaked at $4 \mathrm{hr}$, but persisted for $>24 \mathrm{hr}$, still greater than untreated cultures at $24 \mathrm{hr}$. Synaptophysin and synaptotagmin-I were unchanged as measured by reprobing the same blot. $N R G S T D$ corresponds to an 800 bp RNA loading standard added immediately after cell lysis for quantitation. $B$, Quantitation of the Northern blot data presented in $A$.

\section{BDNF and NT-3 differentially regulate NRG isoforms}

A structural feature common to all of the NRGs is an EGF-like domain that when expressed alone can evoke most of their known biological activities (Holmes et al., 1992; Wen et al., 1994; Loeb and Fischbach, 1995). Many of the NRG isoforms identified thus far have an IG-like domain, $\mathrm{N}$ terminal to the EGF-like domain that binds heparin and is required for extracellular matrix binding (Loeb and Fischbach, 1995). We have shown previously that a probe specific for the EGF-like domain recognizes three tran- 


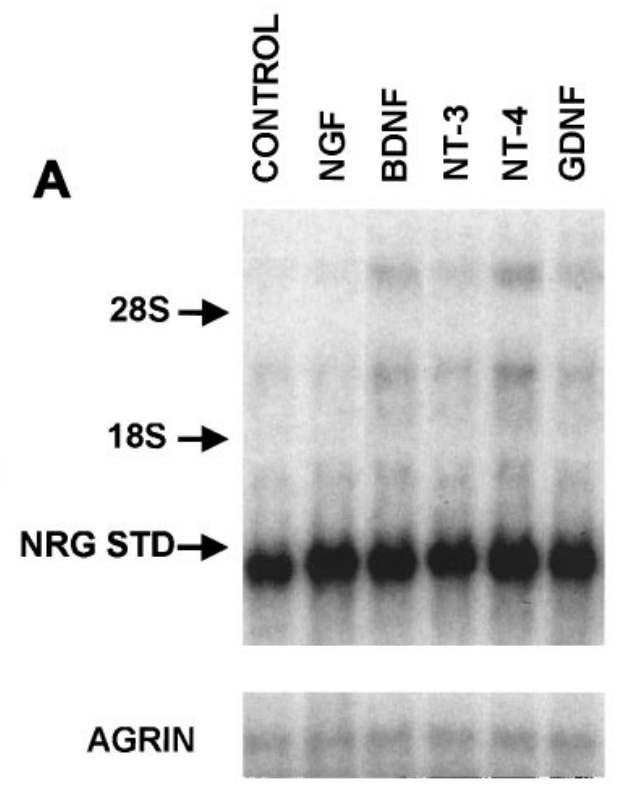

B

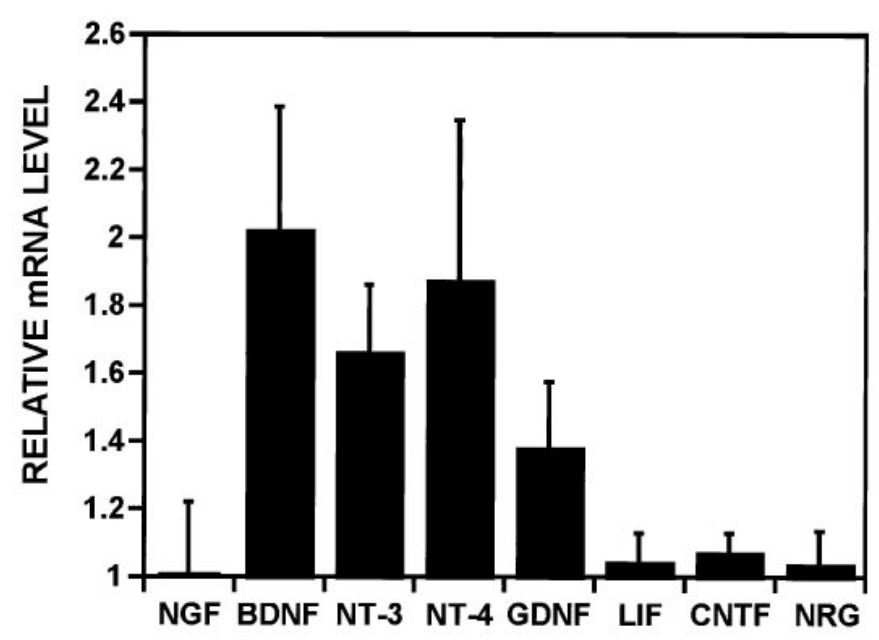

Figure 3. A subset of neurotrophic factors stimulate NRG expression. $A$, Neurons treated with carrier (CONTROL), NGF, BDNF, NT-3, NT-4, or $G D N F$ at $100 \mathrm{ng} / \mathrm{ml}$ each for $4 \mathrm{hr}$ were analyzed by Northern blots first probed for NRG and then reprobed with an agrin probe shown below. In this particular blot, the density of the cultures was lower than in Figure 2 , demonstrating a reduced intensity of the top transcript and a corresponding increase intensity of the NRG standard RNA. $B$, The results of these and other experiments (all performed as in $A$ ) were quantified by normalizing each of the three transcripts to the NRG loading standard and expressing the sum of the three transcripts as a ratio to untreated control cultures. The results are expressed as the average normalized values \pm SEM with NGF, $n=5$; BDNF, $n=6$; NT-3, $n=6$; NT-4, $n=2$; GDNF, $n=2$; LIF, $n=3$; CNTF, $n=3$; NRG, $n=3$.

scripts of 12,9 , and $3.5 \mathrm{~kb}$ on Northern blot analysis, but a probe specific for the IG-like domain recognizes predominantly the 12 kb transcript (Corfas et al., 1995). Therefore, we examined the expression of the IG-containing isoforms by quantifying the $12 \mathrm{~kb}$ transcript with increasing concentrations of either BDNF or NT-3 (Fig. 4). This transcript was upregulated by BDNF but not by NT-3. Although the half-maximal effect for BDNF was $\sim 10 \mathrm{pm}$

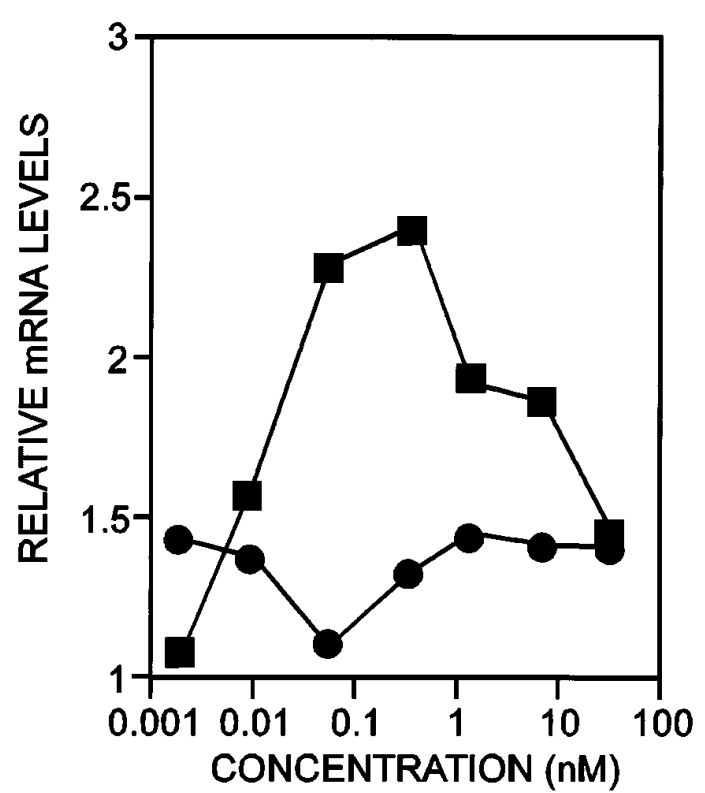

Figure 4. Immunoglobulin domain-containing forms of NRG are differentially regulated by BDNF and NT-3. The top $12 \mathrm{~kb}$ transcript of NRG that encodes for forms containing the IG-like domain was measured from cultures of ventral spinal neurons treated with increasing concentrations of either BDNF (ם) or NT-3 (O). The data were quantified as in Figure 3.

(140 pg/ml), concentrations higher than $1 \mathrm{nM}(14 \mathrm{ng} / \mathrm{ml})$ had a reduced effect. In contrast to the IG-containing forms, the two lower transcripts were upregulated by both BDNF and NT-3 with similar half-maximal effects of $\sim 10 \mathrm{pm}$ and no reduction at higher concentrations.

We next asked whether the upregulation of NRG mRNA also results in an increase in NRG activity released into the medium of these cultures. We observed a 15- and sixfold increase in NRG activity in the medium of cultures treated with either BDNF or NT-3, respectively, for $3 \mathrm{~d}$ (Fig. 5A). NRG activity was measured by NRG receptor tyrosine phosphorylation (p185) in L6 muscle cells. When this released material was mixed with heparin before the assay, most of the activity induced by BDNF, but no significant reduction of activity induced by NT-3, was observed (Fig. $5 B$ ). We have shown previously that splice variants containing the IG-like domain in their N-termini are inhibited by soluble heparin (Loeb and Fischbach, 1995). Thus, both at the protein and the mRNA levels, our results are consistent with a selective induction of IG-containing isoforms of NRG by BDNF, but not by NT-3.

\section{NRG induction by BDNF occurs in motor neurons}

Although our cultures contained both motor neurons and a variety of other neurons from the ventral spinal cord, we believe that it is the smaller population of motor neurons that are responding to the neurotrophic factors. In situ hybridization studies have shown previously that NRG is highly expressed in motor neurons from E17 and P17 rat spinal cords (Corfas et al., 1995). Figure 6, $A$ and $B$, shows that motor neurons from E15 spinal cord, from which our cultures were prepared, are labeled both with antibodies against the motor neuron marker islet- $1 / 2$ and with a panNRG in situ probe against the EGF-like domain.

In 3-d-old ventral spinal cord cultures treated for $4 \mathrm{hr}$ with BDNF, we found that a small percentage of neurons became intensely labeled for NRG message (Fig. 6D,F) compared with untreated cultures (Fig. 6C,E). Many, but not all, of the neurons 


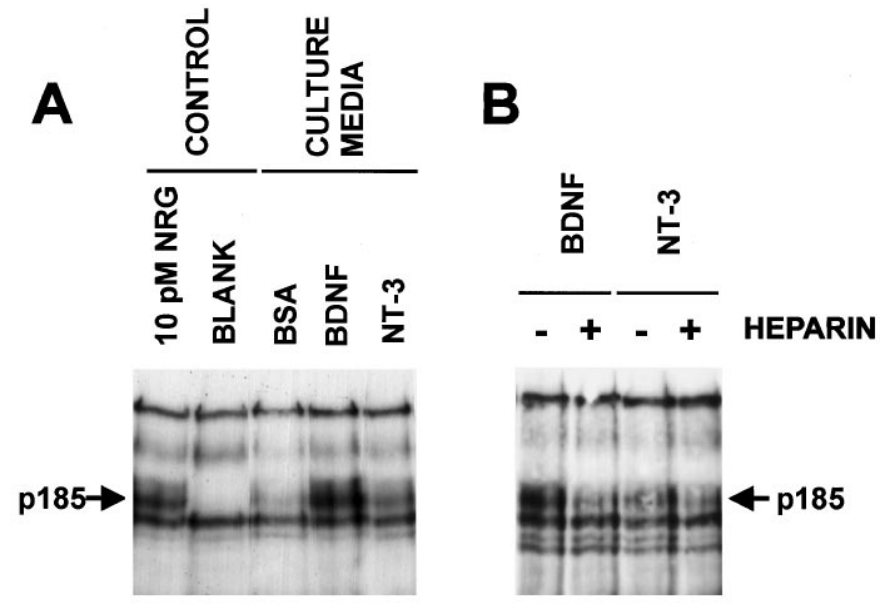

Figure 5. BDNF and NT-3 increase NRG activity released from cultured ventral spinal neurons. $A$, Three-day-old ventral spinal cord neuronal cultures were treated with $100 \mathrm{ng} / \mathrm{ml}$ BDNF, NT-3, or BSA carrier in L15 Glutamax medium alone for $3 \mathrm{~d}$. NRG activity was measured by tyrosine phosphorylation of the NRG receptor p185 by Western blot analysis of the L6 cells. L6 cells were also treated with or without 10 pM NRG as negative and positive controls. $B$, NRG activity induced by BDNF, but not NT-3, was inhibited by soluble heparin $(500 \mu \mathrm{g} / \mathrm{ml})$.

intensely labeled by the NRG probe also stained for the motor neuron marker islet-1/2 after treatment of similar cultures with BDNF for $4 \mathrm{hr}$ (Fig. 7). When we counted the number of in situ grains per islet- $1 / 2$ neuron, we found that the number of cells with $>16$ grains ( 3 SDs above the background mean) increased from 15 to $32 \%$ after $4 \mathrm{hr}$ of BDNF treatment. In fact, the total number of in situ grains in this group increased by 2.5 -fold, consistent with the increase in NRG message we observed on Northern blots. Not all islet-1/2-positive neurons were highly labeled after exposure to BDNF. Additional studies are needed to determine whether this reflects the expected distribution of grains or variations in motor neuron sensitivity to BDNF.

\section{NRG does not affect BDNF or NT-3 expression in cultured myotubes}

We searched for a reciprocal effect of NRG on BDNF and NT-3 expression in cultured embryonic muscle. A reciprocal induction of neurotrophic factors by NRG in developing muscle may complete a regulatory loop between these two sets of factors. However, thus far we have observed no effects of NRG on BDNF or NT-3 mRNA expression in cultured rat myotubes (differentiated for $5 \mathrm{~d}$ ) at levels of NRG that produced a striking induction of the $\epsilon$ AChR-subunit (Fig. 8) (Martinou et al., 1991).

\section{DISCUSSION}

NRG induction at the time of motor neuron innervation may be mediated by target-derived neurotrophic factors

We have examined the developmental expression of the NRGs in rat spinal motor neurons. NRG mRNA increased in two waves. The first occurred between E13 and E14, just after the initial motor axon outgrowth into early muscle masses, and the second occurred between E17 and P1, when more elaborate synaptic connections are being formed (Bevan and Steinbach, 1977; Altman and Bayer, 1984). Despite the appearance of two phases, we suspect that there is a steady increase in NRG mRNA per motor neuron throughout this period of embryonic development. Few, if any, motor neurons are born after E13. The dip that interrupts the steady increase in mRNA probably reflects the fact that programmed motor neuron cell death is maximal on E15 and E16 (Harris and McCaig, 1984).

We have explored the possibility that this induction of NRG expression in vivo may be mediated by target-derived neurotrophic factors. We demonstrate that neurotrophic factors normally expressed in target muscles during this developmental stage increase NRG expression in dissociated ventral spinal cord neurons maintained in vitro. Specifically, BDNF, NT-3, NT-4, and GDNF, but not other neurotrophic factors such as NGF, CNTF or LIF, increased NRG mRNA and protein levels. The effect was rapid, occurring within $4 \mathrm{hr}$, and it was selective in that no change was detected in mRNA that encodes common synaptic vesicle proteins or agrin. We consistently saw a greater effect with BDNF or NT-4, which bind to the $t r k B$ receptor, than with NT-3 or GDNF. The combination of saturating concentrations of BDNF with NT-3 or GDNF produced only partially additive effects, suggesting that these neurotrophic factors may share some signaling pathways or may affect different populations of neurons. Even though mice lacking receptors for either CNTF or LIF have profound losses of spinal motor neurons (DeChiara et al., 1995; Li et al., 1995), we saw no effect of these ligands on NRG expression. This, together with the rapid rate of NRG message induction over the basal level of expression, suggests that regulation of NRG expression by BDNF, NT-3, NT-4, and GDNF is not simply reflecting greater motor neuron survival.

The lack of neurotrophic factor influence on spinal cord agrin mRNA levels under the same conditions, which resulted in a large increase in NRG expression, is particularly interesting. Agrin and ARIA both influence the accumulation of postsynaptic AChRs during neuromuscular junction formation, and they both act at approximately the same time. Agrin and NRG expression are clearly not regulated in exactly the same way.

The sequential expression of these neurotrophic factors in muscle is consistent with their working individually or in combination to modulate the levels of motor neuron NRG expression needed for the development and maintenance of prenatal and postnatal postsynaptic structures. NT-3 and GDNF have been detected in rat muscle by E13 (Schecterson and Bothwell, 1992; Trupp et al., 1995), the time of initial nerve-muscle contact. BDNF has been detected in limb buds as early as E15 (Henderson et al., 1993). All three of these factors steadily decline after birth, and NT-4 rises to become the most prominent of the group by the third postnatal week (Funakoshi et al., 1995). Given that BDNF, NT-3, and GDNF all are expressed in muscle at the time of early innervation, it seems likely that this redundancy may prevent any appreciable loss of motor neuron numbers in individually targeted gene disruptions (for review, see Snider, 1994; Moore et al., 1996; Sanchez et al., 1996). Combinations of these factors may need to be lost to see significant reductions in the number of spinal motor neurons or to see a significant reduction of NRG expression in motor neurons.

Regulation of NRGs by neurotrophic factors may be even more complex, because the expression of neurotrophic factors is not limited to muscle. They are also expressed in developing spinal cord and glia. BDNF and NT-3 are expressed in motor neurons themselves (Schecterson and Bothwell, 1992; Kahane et al., 1996), and BDNF, NT-3, and GDNF are expressed in peripheral nerve glia (Funakoshi et al., 1993; Henderson et al., 1994). Thus, paracrine and autocrine sources of neurotrophic factors may work together with retrogradely transported neurotrophic factors from target muscle cells. Before 

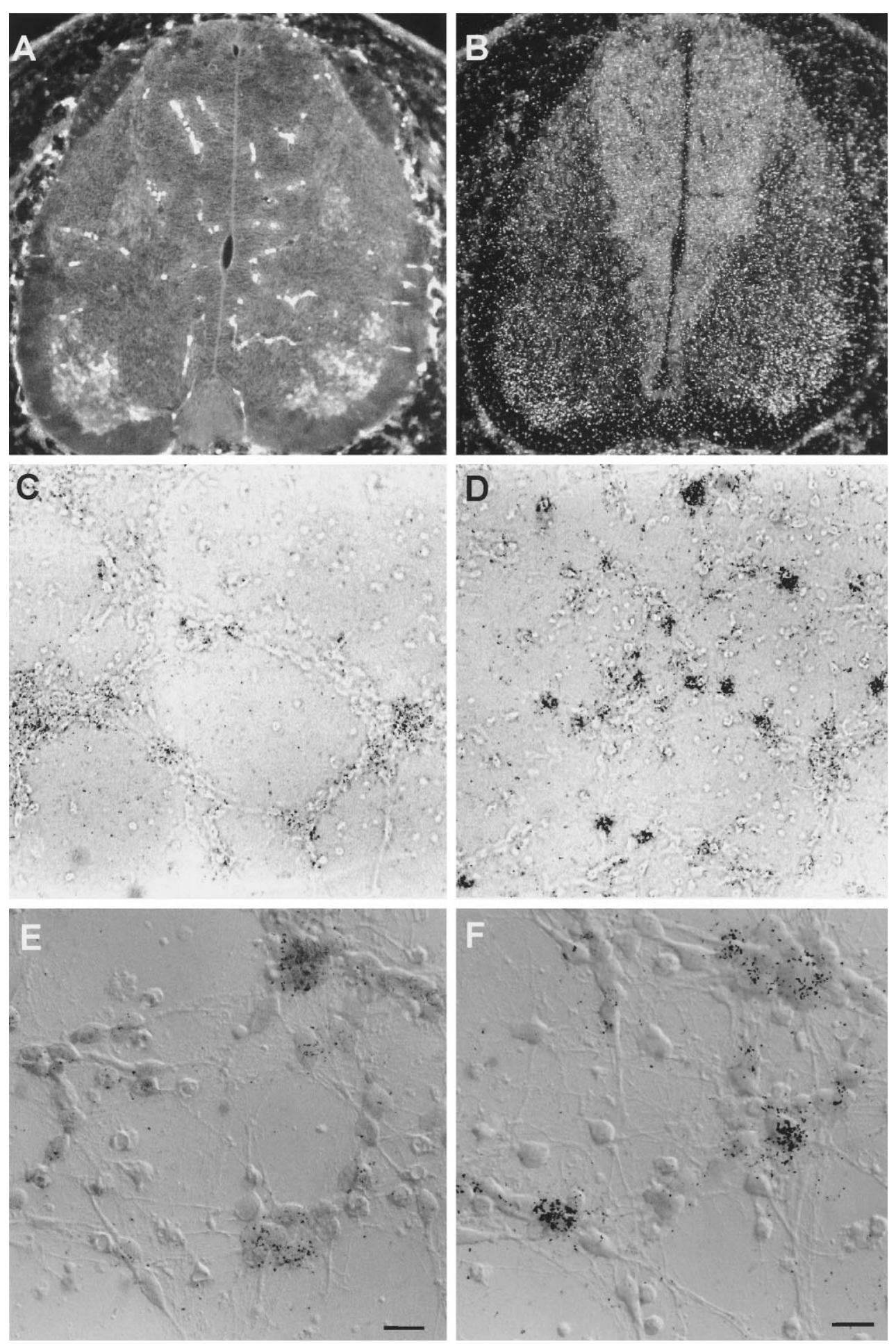

Figure 6. NRG is expressed in spinal motor neurons and induced in a small proportion of cultured ventral neurons by BDNF. Motor neurons can be seen in the ventrallateral portion of the spinal cord in a transverse brachial section from E15 rat, double-labeled with islet-1/2 immunofluorescence $(A)$ and NRG mRNA by radioactive in situ hybridization $(B)$. Ventral spinal cord neuronal cultures were treated without $(C, E)$ or with $(D, F)$ BDNF (100 $\mathrm{ng} / \mathrm{ml}$ ) for $4 \mathrm{hr}$ and analyzed by radioactive in situ hybridization for NRG message. Only a small proportion of neurons increased their expression of NRG in response to BDNF. $C$ and $D$ are low-power $(20 \times$ objective) bright-field images, and $E$ and $F$ are combined DIC and bright-field higherpower images of neurons using a $60 \times$ oil emersion objective. Scale bars, $10 \mu \mathrm{m}$. axonal contact with muscle, NRG expression may be supported entirely by local actions in the spinal cord and developing peripheral nerve. For example, a switch in source of support may occur, because NT-3 is highly expressed in rat spinal motor neurons only between E13 and E16, after which it declines and eventually disappears by P1 (Ernfors and Persson, 1991).

\section{BDNF and NT-3 differentially regulate extracellular matrix-binding isoforms of NRG}

NRGs are the most likely candidates for maintaining high local levels of AChR expression in subsynaptic nuclei. The local and persistent action may depend on accumulation of inducers in the synaptic basal lamina. A critical NRG concentration may be required for $e r b B$ receptor activation and may depend on such a reservoir. We have previously obtained biochemical (Loeb and Fischbach, 1995) and immunohistochemical evidence (Goodearl et al., 1995) suggesting that isoforms of NRG possessing an $\mathrm{N}$-terminal IG-like domain can bind to heparin-like molecules and accumulate in the extracellular matrix. Forms that lack the IG domain do not bind to the surface matrix. Earlier work had shown that AChR-inducing activity persists at denervated junctions long 

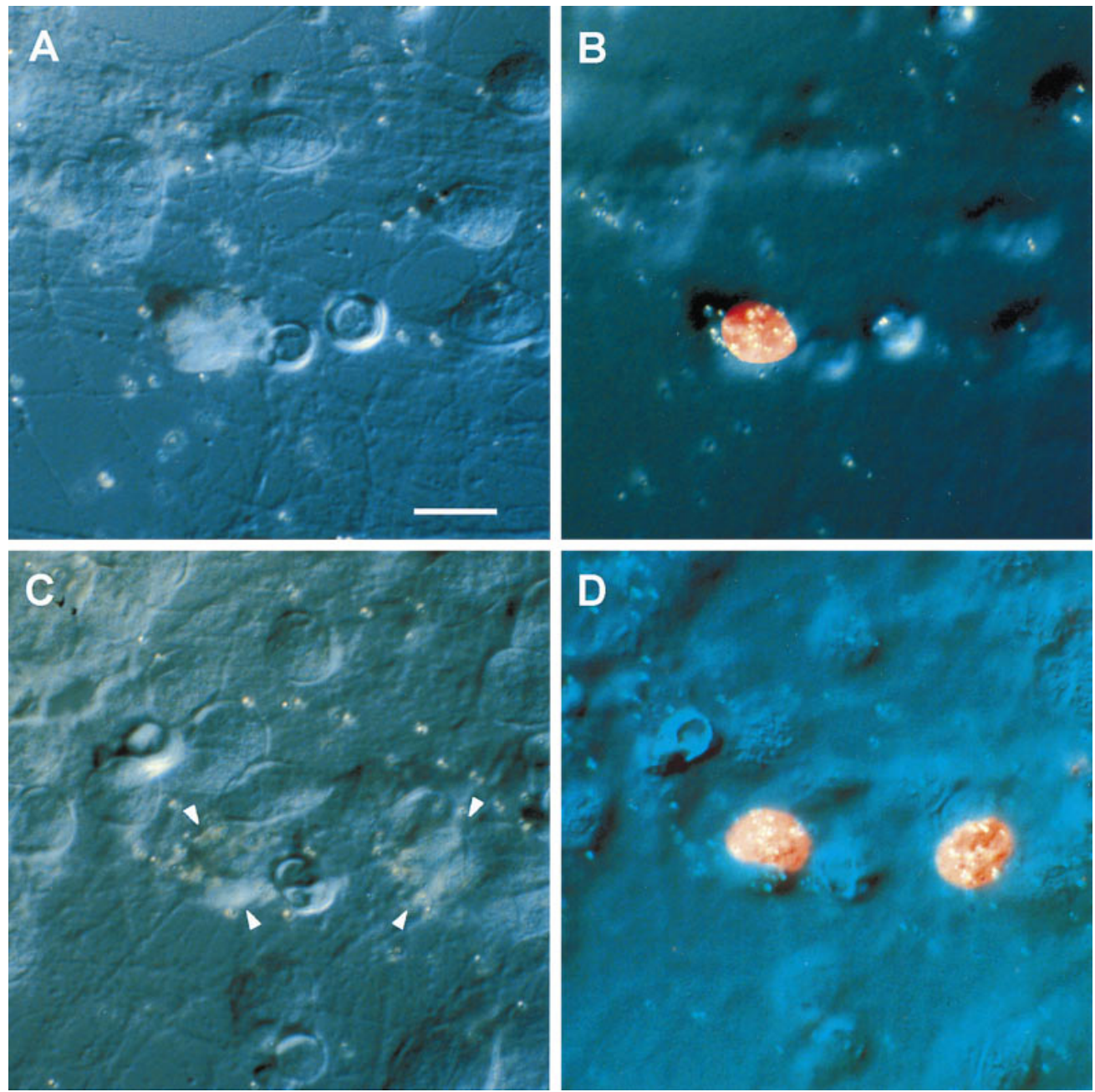

Figure 7. NRG message is increased in motor neurons. Ventral spinal neuronal cultures were treated with BDNF for 4 hr and then double-labeled with islet-1/2 immunofluorescence and in situ hybridization for NRG message. Two examples of motor neurons double-labeled with islet-1/2 nuclei and NRG mRNA are shown in $B$ and $D$ by digitally fusing the islet-1/2 immunofluorescence images with DIC images taken at a high focal plane through the emulsion. Corresponding DIC images of the neurons were taken on a lower focal plane $(A, C)$ with arrows marking the cell bodies in $C$, where the margins are less distinct.

\section{TIME (hrs) $\quad 0 \quad 2 \quad 4 \quad 6 \quad 8 \quad 24$}

Figure 8. NRG does not increase BDNF or NT-3 expression in primary myotube cultures. Primary myotube cultures were treated for increasing periods of time with $1 \mathrm{~nm}$ NRG (NDF $\beta 1_{14-246}$ ). Whereas the myotubes responded rapidly by increasing the expression of the $\epsilon$-subunit of the AChR within $4 \mathrm{hr}$, there was no effect on BDNF or NT-3 expression measured by reprobing the same Northern blot. The top transcript of the $\epsilon$-subunit likely corresponds to an mRNA precursor. The bottom panel demonstrates a second reprobing for glyceraldehyde-3-phosphate dehydrogenase to demonstrate uniformity of loading.

after the motor nerve terminals degenerate. This matrix-bound inducing activity is presumably responsible for the high level of postsynaptic AChRs at denervated endplates (Goldman et al.,
BDNF

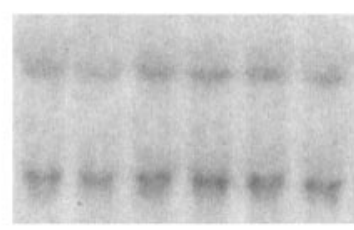

$\begin{array}{llllll}0 & 2 & 4 & 6 & 8 & 24\end{array}$

NT-3

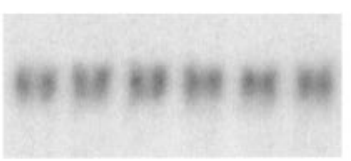

$\varepsilon-A C h R$

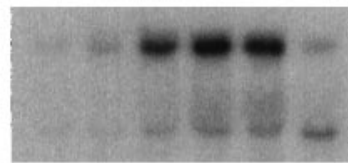

E-AChR

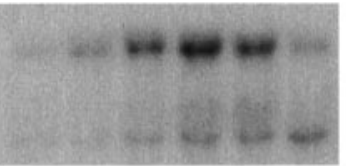

GAPDH

1991; Brenner et al., 1992; Jo at al., 1995). It is significant, therefore, that BDNF appears to exert a relatively selective effect on mRNA transcripts that encode IG-containing NRG isoforms. 
This conclusion is based on the inhibition of IG domaincontaining isoforms by soluble heparin and analysis of Northern blot transcripts. The effect is not mimicked by NT-3. The stimulatory effect for BDNF, curiously, occurs over a narrow concentration range, such that concentrations of BDNF too high or too low will not induce these isoforms. In contrast, other isoforms appear to be induced equally well by BDNF and NT-3.

A splice variant called sensory and motor neuron differentiation factor has been cloned that lacks this IG-like domain and in its place, has a unique N-terminal region (Ho et al., 1995). Transfected cells expressing this form release soluble activity into the medium. It is possible that this isoform represents a freely diffusible, nonmatrix-binding form of NRG. Thus, it may be possible in vivo that both matrix-bound and soluble forms of NRG could be differentially regulated by both the type and the concentration of neurotrophic factor exposed to the motor neuron.

\section{A regulatory loop}

We suggest that the upregulation of NRG mRNA in motor neurons can be considered part of a regulatory loop in which muscle-derived proteins stimulate the synthesis of presynaptic proteins that, in turn, regulate the differentiation of the muscle motor endplate. Reciprocal regulatory events at the neuromuscular junction have long been suspected (for review, see Hall and Sanes, 1993). A similar type of regulatory interaction has been elegantly documented for sympathetic neurons that change their phenotype from noradrenergic to cholinergic as a result of reciprocal regulatory signals with their target sweat glands (Schotzinger et al., 1994). Interplay between the NRGs and neurotrophins has been documented earlier in sympathetic neuron development. Glial growth factor-2, an NRG that has an unusually long $\mathrm{N}$-terminal segment preceding the IG-like domain, was found to increase NT-3 mRNA in adjacent non-neuronal cells within embryonic sympathetic ganglia, which in turn, affects the differentiation of the sympathetic neurons (Verdi et al., 1996). We did not observe any reverse effects of NRGs on the regulation of BDNF or NT-3 mRNA in cultured embryonic muscle. Additional experiments with different NRG isoforms and with muscle in different stages of development are needed to rule out a reciprocal interaction between NRGs and neurotrophins in muscle.

Although we saw no effects of NRG on the expression of BDNF or NT-3 in muscle, neuronal activity has been shown to modulate the expression of neurotrophins both in muscle (Meyer et al., 1992; Funakoshi et al., 1993, 1995) and in the CNS (for review, see Lewin and Barde, 1996). Activity-dependent regulation of neurotrophin expression has been suggested to be an important mediator of synaptic plasticity both in the CNS and at the neuromuscular junction. In the case of the neuromuscular synapse, NT-4 has been shown to be upregulated in muscle by neuronal activity postnatally as BDNF and NT-3 levels fall (Funakoshi et al., 1995). Because neuronal activity also leads to a profound decrease in extrajunctional AChR synthesis, it is remarkable that AChR gene expression remains high in subsynaptic nuclei and so does the synthesis of AChRs at endplates (for review, see Hall and Sanes, 1993). It is attractive to think that the persistence in local AChR synthesis is attributable to an activity-dependent upregulation of NT-4 or related molecules that then leads to a subsequent increase in NRG synthesis and deposition in the synaptic cleft. This might provide a mechanism for fine tuning of AChR synthesis in the face of varying levels of impulse activity. In this manner, differentiation factors on both sides of the developing synapse, coupled with electrical activity, may work together to orchestrate the complex developmental events needed for the formation of a stable neuromuscular synapse.

\section{REFERENCES}

Altiok N, Bessereau JL, Changeux JP (1995) ErbB3 and ErbB2/neu mediate the effect of heregulin on acetylcholine receptor gene expression in muscle: differential expression at the endplate. EMBO $\mathbf{J}$ 14:4258-4266.

Altman J, Bayer SA (1984) The development of the rat spinal cord. Adv Anat Embryol Cell Biol 85:1-164.

Bevan S, Steinbach JH (1977) The distribution of alpha-bungarotoxin binding sites of mammalian skeletal muscle developing in vivo. J Physiol (Lond) 267:195-213.

Brenner HR, Herczeg A, Slater CR (1992) Synapse-specific expression of acetylcholine receptor genes and their products at original synaptic sites in rat soleus muscle fibers regenerating in the absence of innervation. Development 116:41-53.

Carraway III KL, Cantley LC (1994) A neu acquaintance for erbB3 and erbB4: a role for receptor heterodimerization in growth signaling. Cell 78:5-8.

Corfas G, Rosen KM, Aratake H, Krauss R, Fischbach GD (1995) Differential expression of ARIA isoforms in the rat brain. Neuron 14:103-115.

Daniels MP (1990) Localization of actin, beta-spectrin, 43 x 10(3) Mr and $58 \times 10$ (3) $\mathrm{Mr}$ proteins to receptor-enriched domains of newly formed acetylcholine receptor aggregates in isolated myotube membranes. J Cell Sci 97:615-626.

DeChiara TM, Vejsada R, Poueymirou WT, Acheson A, Suri C, Conover JC, Friedman B, McClain J, Pan L, Stahl N, Ip NY, Kato A, Yancpoulos GD (1995) Mice lacking the CNTF receptor unlike mice lacking CNTF, exhibit profound motor neuron deficits at birth. Cell 83:313-322.

Ernfors P, Persson H (1991) Developmentally regulated expression of HDNF/NT-3 mRNA in rat spinal cord motoneurons and expression of BDNF mRNA in dorsal root ganglia. Eur J Neurosci 3:953-961.

Falls DL, Rosen KM, Corfas G, Lane W, Fischbach GD (1993) ARIA, a protein that stimulates acetylcholine receptor synthesis is a member of the neu ligand family. Cell 72:801-815.

Funakoshi H, Frisen J, Barbany G, Timmusk T, Zachrisson O, Verge VM, Persson H (1993) Differential expression of mRNAs for neurotrophins and their receptors after axotomy of the sciatic nerve. J Cell Biol 123:455-465.

Funakoshi H, Belluardo N, Arenas E, Yamamoto Y, Casabona A, Persson $\mathrm{H}$, Ibanez CF (1995) Muscle-derived neurotrophin-4 as an activitydependent trophic signal for adult motor neurons. Science 268:1495-1499.

Gautam M, Noakes PG, Moscoso L, Rupp F, Scheller RH, Merlie JP, Sanes JR (1996) Defective neuromuscular synaptogenesis in agrindeficient mutant mice. Cell 85:525-535.

Goldman D, Carlson BM, Staple J (1991) Induction of adult-type nicotinic acetylcholine receptor gene expression in noninnervated regenerating muscle. Neuron 7:649-658.

Goodearl AD, Yee AG, Sandrock Jr AW, Corfas G, Fischbach GD (1995) ARIA is concentrated in the synaptic basal lamina of the developing chick neuromuscular junction. J Cell Biol 130:1423-1434.

Hall ZW, Sanes JR (1993) Synaptic structure and development: the neuromuscular junction. Neuron 10[Suppl]:99-121.

Harris AJ, McCaig CD (1984) Motoneuron death and motor unit size during embryonic development of the rat. J Neurosci 4:13-24.

Henderson CE, Camu W, Mettling C, Gouin A, Poulsen K, Karihaloo M, Rullamas J, Evans T, McMahon SB, Armanini MP, Bertemeier L, Phillips HS, Rosenthal A (1993) Neurotrophins promote motor neuron survival and are present in embryonic limb bud. Nature 363:266-270.

Henderson CE, Phillips HS, Pollock RA, Davies AM, Lemeulle C, Armanini M, Simmons L, Moffet B, Vandlen RA, Simpson LC, Koliatsos VE, Rosenthal A (1994) GDNF: a potent survival factor for motoneurons present in peripheral nerve and muscle. Science 266:1062-1064.

Ho WH, Armanini MP, Nuijens A, Phillips HS, Osheroff PL (1995) Sensory and motor neuron-derived factor. A novel heregulin variant highly expressed in sensory and motor neurons. J Biol Chem 270:14523-14532.

Holmes WE, Sliwkowski MX, Akita RW, Henzel WJ, Lee J, Park JW, Yansura D, Abadi N, Raab H, Lewis GD, Shepard HM, Kuang W-J, Wood WI, Goedde DI, Vandlen RL (1992) Identification of heregulin, a specific activator of p185 ${ }^{\text {erbB2}}$. Science 256:1205-1210. 
Jing S, Wen D, Yu Y, Holst PL, Luo Y, Fang J, Tamir R, Antonio L, Hu Z, Cupples R, Louis J-C, Hu S, Altrock BW, Fox GM (1996) GDNFinduced activation of the Ret protein tyrosine kinase is mediated by GDNFR- $\alpha$, a novel receptor for GDNF. Cell 85:1113-1124.

Jo SA, Zhu X, Marchionni MA, Burden SJ (1995) Neuregulins are concentrated at nerve-muscle synapses and activate ACh-receptor gene expression. Nature 373:158-161.

Kahane N, Shelton DL, Kalcheim C (1996) Expression and regulation of brain-derived neurotrophic factor and neurotrophin-3 mRNAs in distinct avian motoneuron subsets. J Neurobiol 29:277-292.

Koliatsos VE, Clatterbuck RE, Winslow JW, Cayouette MH, Price DL (1993) Evidence that brain-derived neurotrophic factor is a trophic factor for motor neurons in vivo. Neuron 10:359-367.

Lemke G (1996) Neuregulins in development. Mol Cell Neurosci 7:247-262.

Lewin GR, Barde Y-A (1996) Physiology of the neurotrophins. Annu Rev Neurosci 19:289-317.

Li M, Sendtner M, Smith A (1995) Essential function of LIF receptor in motor neurons. Nature 378:724-727.

Loeb JA, Fischbach GD (1995) ARIA can be released from extracellular matrix through cleavage of a heparin-binding domain. J Cell Biol 130:127-135.

Marchionni MA, Goodearl ADJ, Maio SC, Bermingham-McDonogh O, Kirk C, Hendricks M, Danehy F, Misumi D, Sudhalter J, Kobayashi K, Wroblewski D, Lynch C, Baldassare M, Hales I, Davis JB, Hsuan JJ, Totty NF, Otsu M, McBurney RN, Waterfield MD, Stroobant P, Gwynne D (1993) Glial growth factors are alternatively spliced erbB2 ligands expressed in the nervous system. Nature 362:312-318.

Martinou J-C, Falls DL, Fischbach GD, Merlie JP (1991) Acetylcholine receptor-inducing activity stimulates expression of the $\epsilon$-subunit of the muscle acetylcholine receptor. Proc Natl Acad Sci USA 88:7669-7673.

Meyer M, Matsuoka I, Wetmore C, Olson L, Thoenen H (1992) Enhanced synthesis of brain-derived neurotrophic factor in the lesioned peripheral nerve: different mechanisms are responsible for the regulation of BDNF and NGF mRNA. J Cell Biol 119:45-54.

Moore MW, Klein RD, Farinas I, Sauer H, Armanini M, Phillips H,
Reichardt LF, Ryan AM, Carver-Moore K, Rosenthal A (1996) Renal and neural abnormalities in mice lacking GDNF. Nature 382:76-79.

Moscoso LM, Chu GC, Gautam M, Noakes PG, Merlie JP, Sanes JR (1995) Synapse-associated expression of an acetylcholine receptorinducing protein, ARIA/heregulin, its putative receptors, ErbB2 and ErbB3, in developing mammalian muscle. Dev Biol 172:158-169.

Nastuk MA, Fallon JR (1993) Agrin and the molecular choreography of synapse formation. Trends Neurosci 16:72-76.

Peles E, Yarden Y (1993) Neu and its ligands: from an oncogene to neural factors. Bioessays 15:815-824.

Sanchez MP, Silos-Santiago I, Frisen J, He B, Lira SA, Barbacid M (1996) Renal agenesis and the absence of enteric neurons in mice lacking GDNF. Nature 382:70-73.

Schecterson LC, Bothwell M (1992) Novel roles for neurotrophins are suggested by BDNF and NT-3 mRNA expression in developing neurons. Neuron 9:449-463.

Schotzinger R, Yin X, Landis S (1994) Target determination of neurotransmitter phenotype in sympathetic neurons. J Neurobiol 25:620-639.

Snider WD (1994) Functions of the neurotrophins during nervous system development: what the knockouts are teaching us. Cell 77:627-638.

Trupp M, Ryden M, Jornvall H, Funakoshi H, Timmusk T, Arenas E, Ibanez CF (1995) Peripheral expression and biological activities of GDNF, a new neurotrophic factor for avian and mammalian peripheral neurons. J Cell Biol 130:137-148.

Verdi JM, Groves AK, Farinas I, Jones K, Marchionni MA, Reichardt LF, Anderson DJ (1996) A reciprocal cell-cell interaction mediated by NT-3 and neuregulins controls the early survival and development of sympathetic neuroblasts. Neuron 16:515-527.

Wen D, Suggs SV, Karunagaran D, Liu N, Cupples R, Luo Y, Jansen ZM, Ben-Baruch N, Trollinger DB, Jacobsen VL, Meng HY, Lu HS, Hu S, Chang D, Yang W, Yanigahara D, Koski RA, Yarden Y (1994) Structural and functional aspects of the multiplicity of Neu differentiation factors. Mol Cell Biol 14:1909-1919.

Zhu X, Lai C, Thomas S, Burden SJ (1995) Neuregulin receptors, erbB3 and erbB4, are localized at neuromuscular junctions. EMBO J 14:5842-5848. 